\title{
Intestinal helminthes and/or Toxocara infection are unrelated to anti-HBs titers in seven-year-old children vaccinated at birth with recombinant hepatitis $B$ vaccine
}

\author{
Helmintos intestinais e/ou infecção por Toxocara não tem relação com títulos \\ de anti-HBs em crianças de sete anos de idade vacinadas ao nascer \\ com vacina recombinante para hepatite $B$
}

\author{
Marisa B.C.L. Monteiro ${ }^{1}$, Roberta Fragoso ${ }^{1}$, Silvio Foletto ${ }^{2}$, \\ Elenice M. Lemos ${ }^{1}$ and Fausto E.L. Pereira ${ }^{1}$
}

\begin{abstract}
The aim of this investigation was to evaluate the possible effect of nematode infection on anti-HBs antibody levels in the serum of sevenyear-old schoolchildren vaccinated at birth with the recombinant hepatitis B vaccine. Anti-HBs and anti HBc antibodies were evaluated in the sera of 100 schoolchildren with at least one intestinal nematode and/or a positive serological reaction for anti-Toxocara antibodies and in 95 schoolchildren without intestinal helminthiasis or serum anti-Toxocara antibodies. Both groups were from public elementary schools located on the urban periphery of Vitória, ES, Brazil. Among these 195 children, the median anti-HBs antibody titer was 31.3IU/ml and the frequency of titers less than 10IU/ml was 33.8\% (95\% CI: 27.1-40.4\%). There were no significant differences between the medians of anti-HBs titers or the frequency of titers less than 10IU/ml between the groups with or without helminthes (29.5 and 32.9IU/ml and 33 and 34.7\%, respectively; $p>0.05$ ). Even when the children with intestinal nematodes and/or anti-Toxocara antibodies and with blood eosinophil counts over 600/mm ${ }^{3}$ were compared with children without infection from intestinal nematodes and without anti-Toxocara antibodies, with blood eosinophil counts less than 400 eosinophils $/ \mathrm{mm}^{3}$, these differences were not significant. None of the children presented anti-HBc antibodies. In conclusion, infections with intestinal nematodes and/or the presence of anti-Toxocara antibodies did not interfere with the anti-HBs antibody titers in seven-year-old children vaccinated at birth with the recombinant hepatitis B vaccine.
\end{abstract}

Key-words: Intestinal nematodes. Toxocariasis. Hepatitis B vaccine. Helminthiasis.

\section{RESUMO}

O objetivo dessa investigação foi avaliar um possível efeito de infecções por nematóides sobre os níveis de anticorpos anti-HBs no soro de escolares de sete anos de idade, vacinados ao nascer com a vacina recombinante para hepatite B. Anticorpos anti-HBs e anti-HBc foram avaliados no soro de 100 escolares portadores de pelo menos um nematóide intestinal elou uma reação sorológica positiva para anticorpos anti-Toxocara e em 95 escolares sem helmintíases intestinais e sem anticorpos séricos anti-Toxocara, todos matriculados em escolas primárias públicas situadas na periferia urbana de Vitória, ES, Brasil. Nas 195 crianças, a mediana dos títulos dos anticorpos anti-HBs foi 31,3UI/ml, e a freqüência de títulos inferiores a 10UI/ml foi de 33,8\% (IC a 95\%:27,1- 40,4\%). Não bouve diferença significativa entre as medianas dos títulos de anti-HBs ou da freqüência de títulos inferiores a $10 \mathrm{UI} / \mathrm{ml}$ entre as crianças com ou sem helmintos (29,5 e 32,9 UI/ml e 33 e 34,7\%, respectivamente; $p>0.05)$. Mesmo quando comparadas crianças com nematóides intestinais e/ou anticorpos anti-Toxocara com eosinófilos circulantes acima de 600/ $\mathrm{mm}^{3}$, com crianças sem infecção com nematóides intestinais e sem anticorpos anti-Toxocara, com menos de 400 eosinófilos $/ \mathrm{mm}^{3}$, aquelas diferenças não foram significativas. Nenhuma das crianças apresentou anticorpos anti-HBc. Em conclusão, infecções com nematóides intestinais e/ou presença de anticorpos anti-Toxocara não interferem nos títulos de anticorpos anti-HBs em crianças de sete anos de idade, vacinadas ao nascer com a vacina recombinante para hepatite $B$.

Palavras-chaves: Nematóides intestinais. Toxocaríase. Vacina para hepatite B. Helmintíases.

\footnotetext{
1. Núcleo de Doenças Infecciosas, Centro de Ciências da Saúde, Universidade Federal do Espirito Santo, Vitória, ES. 2. Central Sorológica de Vitória, Vitória, ES. This research was supported by Cia Siderúrgica de Tubarão-Acelor-Brasil, Fundação de Apoio ao Hospital Universitário Cassiano A Moraes and Central Sorológica de Vitória. Address to: Dr. Fausto E.L. Pereira. Núcleo de Doenças Infecciosas/CCS/UFES. Av Marechal Campos 1468, Maruipe, 29040-091, Vitória, ES.

e-mail: felp@ndi.ufes.br

Recebido para publicação em 18/10/2006

Aceito em 20/3/2007
} 
Serum anti-HBs antibodies acquired after a complete course of primary vaccination with the hepatitis $B$ recombinant vaccine fall progressively over the course of the years following vaccination, to a greater or lesser extent ${ }^{27} 28$. Factors such as birth weight, HBs antigen positivity in the mother and the magnitude of the response to vaccination are related to the rate of anti-HBs decay, but the role of environmental factors like nutrition and parasite infection have not been studied ${ }^{28}$.

Helminth infection induces immunomodulation, by skewing the immune response to the Th2 pole and inducing the activation of different types of regulatory $\mathrm{T}$ cells ${ }^{131415}$. Corroborating this immune deregulation, increased prevalence of some infectious diseases like staphylococcal infection, tuberculosis and leprosy has been reported in individuals with intestinal worms and/or Toxocara infection ${ }^{5171824}$. In addition, this immunomodulation may interfere with the response of several vaccines, as demonstrated in experimental models and in humans. In these studies, impairment of the production of protective antibodies, the induction of cell-mediated immunity and the anamnestic response have been reported 34710161921 . Children with nematode infection presented significantly lower responses to PPD and, when vaccinated with BCG, became less reactive to that antigen but presented an improved response following worm eradication ${ }^{7}$. Thus, there is evidence that helminth infection may interfere with the anamnestic response to vaccines.

With regard to $\mathrm{HBV}$ vaccine, Ghaffar et $\mathrm{al}^{11}$ reported lower anti-HBs response in children with schistosomiasis, three and nine months after vaccination. However, Bassily et $\mathrm{al}^{2}$ did not find any effects from maternal infection with Schistosoma mansoni on the anti-HBs titers of babies vaccinated at birth.

Hepatitis vaccination induces protective anti-HBs antibodies. Although it is accepted that anti-HBs titers higher than $10 \mathrm{IU} /$ indicate protection, this protection does exist with lower titers because of the anamnestic response involving $\mathrm{T}$ cells $^{28}$. It is not known how the immunological memory and high production of protective anti-HBs titers are maintained, but the mechanisms involved may include: (a) generation of long-lived plasma cells, and (b) frequent stimulation of $\mathrm{B}$ and T memory cells by contact with cross-reactive epitopes or through bystander stimulation after nonspecific polyclonal activators have been in contact with the immune system ${ }^{12}$. The latter mechanisms, which are dependent on stimulation of memory cell clones, may be influenced by the status of the immune system. This may include immunomodulation induced by worm infection, which would induce bystander suppression of memory cells. Thus, it is plausible that introduction of helminth infection in children who received hepatitis B vaccine at birth could induce impairment of the titers of protective anti-HBs antibodies in the first years of life. To investigate this possibility, we evaluated and compared the anti-HBs titers in seven-year-old children, with or without intestinal helminthes and/or positive serology for Toxocara.

\section{MATERIAL AND METHODS}

The anti-HBs titers were evaluated in two groups of sevenyear-old schoolchildren who had been vaccinated at birth with three doses of recombinant hepatitis B vaccine. These children were from eight public elementary schools located in low-income neighborhoods. They were separated in two groups: one group with negative serology for anti-Toxocara antibodies and without intestinal helminthes and another group including children with at least one intestinal helminth (Ascaris lumbricoides in 33 cases, Trichurus trichiura in three cases and both worms in one case) and/or a positive serology for anti-Toxocara antibodies.

All children who are admitted to the public elementary schools in Vitória undergo clinical examination, complete hemogram and stool examination to investigate intestinal parasites. The excess of blood collected for the hemogram was used to obtain the sera for the present study. All sera were stored at $-20^{\circ} \mathrm{C}$.

Anti-HBs and anti $\mathrm{HBc}$ were investigated using commercial kits (Axsyn AUSAB and Axsyn System Core, Abbot Laboratórios do Brasil Ltda), in accordance with the manufacturer's instructions. The tests were performed at Central Sorologica de Vitória.

Anti-Toxocara antibodies were investigated by means of ELISA IgG, using secretion-excretion antigens of second and third-stage larvae of Toxocara canis, in accordance with the manufacturer's instructions (CELISA-Toxocara, Cellabs, Australia). This was performed at Núcleo de Doenças Infecciosas, Federal University of Espírito Santo (UFES). The sera were not adsorbed with other helminth antigens before ELISA testing. In the group considered to be negative for Toxocara, the optical densities were lower than 0.250 , which was considered to be nonreactive by the manufacturer. In the group considered to be Toxocara-positive, the optical densities were higher than 0.500 , and these values were considered indicative of Toxocara infection, according to the manufacturer. The stool examination was performed on a single sample, by the sedimentation method, at the routine laboratory of the municipality of Vitória. The hemogram was performed at the same laboratory, using automated methods.

\section{RESULTS}

The results are shown in Tables 1, 2, 3 and 4. The two groups (with and without helminth infection) were homogeneous, without significant differences in age, gender distribution, lymphocyte counts or hemoglobin concentration (Table 1).

\begin{tabular}{|c|c|c|c|}
\hline \multirow[b]{2}{*}{ Variables } & \multicolumn{2}{|c|}{ Intestinal nematode and/or Toxocara } & \multirow[b]{2}{*}{$\mathrm{p}$} \\
\hline & negative $(\mathrm{N}=95)$ & positive $(\mathrm{N}=100)$ & \\
\hline \multicolumn{4}{|l|}{ Gender } \\
\hline male $(\mathrm{N}=103)$ & 46 & 57 & \\
\hline female $(\mathrm{N}=92)$ & 49 & 43 & $0.788^{\mathrm{a}}$ \\
\hline \multicolumn{4}{|l|}{ Age (years; mean \pm SD) } \\
\hline male & $7.25 \pm 0.54$ & $7.16 \pm 0.48$ & \\
\hline female & $7.27 \pm 0.66$ & $7.42 \pm 0.39$ & \\
\hline Hemoglobin $(\mathrm{mg} / \mathrm{dl}$, mean $\pm \mathrm{SD})$ & $11.95 \pm 0.78$ & $12.17 \pm 0.76$ & $0.188^{b}$ \\
\hline Lymphocyte/mm³ (mean \pm SD) & $2522.8 \pm 608.4$ & $2625.5 \pm 667.1$ & $0.934^{\mathrm{b}}$ \\
\hline
\end{tabular}


There was no undernutrition in either group. This was demonstrated by direct inspection as well as by lymphocyte counts and hemoglobin concentrations (Table 1). The latter are considered to be indirect markers for nutritional status.

The median for the anti-HBs titers for the 195 children studied was $31.3 \mathrm{IU} / \mathrm{ml}$ and the prevalence of titers less than $10 \mathrm{IU} / \mathrm{ml}$ was $33.8 \%$, without gender differences (Table 2).

When the means of anti-HBs titers and the frequency of titers less than $10 \mathrm{IU} / \mathrm{ml}$ were compared between the groups with and without helminth infection, the differences were not significant (Table 3).
Since blood eosinophil counts may provide indirect evidence of stronger Th2 reaction induced by worms, anti-HBs titers were compared between the children without intestinal helminthes and negative for anti-Toxocara antibodies whose blood eosinophil counts were less than $400 / \mathrm{mm}^{3}$, and the children with helminth infection and with blood eosinophil count higher than $600 / \mathrm{mm}^{3}$ (Table 4). Even in this situation, the difference in anti-HBs titers was not significant.

No child in either of the two groups was reactive to antiHBc.

\begin{tabular}{|c|c|c|c|c|}
\hline \multirow[t]{2}{*}{ Groups } & \multicolumn{4}{|c|}{ anti-HBs $(\mathrm{IU} / \mathrm{ml})^{\mathrm{a}}$} \\
\hline & mean $\pm \mathrm{SD}$ & median & $\mathrm{GM}^{\mathrm{b}}$ & $<10 />10(\% ; 95 \% \mathrm{CI})$ \\
\hline All cases $(\mathrm{N}=195)$ & $150.9 \pm 345.2$ & 31.3 & 22.7 & $66 / 129(33.8 ; 27.1-40.4)$ \\
\hline male $(\mathrm{N}=103)$ & $174.5 \pm 392.1$ & 32.0 & 25.3 & $32 / 71(31.1 ; 22.1-40.3)$ \\
\hline female $(\mathrm{N}=92)$ & $124.5 \pm 283.1$ & 29.8 & 20.1 & $34 / 58(36.9 ; 27.0-46.7)^{\mathrm{c}}$ \\
\hline
\end{tabular}

Table 3 - Anti-HBs titers in sera of seven-year-old children vaccinated at birth with recombinant hepatitis $B$ vaccine, according to the presence of at least one intestinal belminth and/or positive serology for Toxocara, in Vitória, ES.

\begin{tabular}{|c|c|c|c|c|}
\hline \multirow{2}{*}{$\begin{array}{l}\text { Intestinal helminth and/or } \\
\text { serology for Toxocara }\end{array}$} & \multicolumn{4}{|c|}{ Anti-HBs (IU/ml) ${ }^{\mathrm{a}}$} \\
\hline & mean \pm SD & median & $\mathrm{GM}^{\mathrm{b}}$ & $<10 />10(\% ; 95 \% \mathrm{CI})$ \\
\hline Negative $(\mathrm{N}=95)$ & $154.3 \pm 59.2$ & 32.9 & 23.7 & $33 / 62(34.7 ; 25.1-44.2)$ \\
\hline Positive $(\mathrm{N}=100)$ & $147.4 \pm 331.9$ & 29.5 & 21.6 & $33 / 67(33.0 ; 23.1-42.2)^{\mathrm{c}}$ \\
\hline
\end{tabular}

\begin{tabular}{|c|c|c|c|c|}
\hline \multirow{2}{*}{$\begin{array}{l}\text { Helminth and/or } \\
\text { serology for Toxocara }\end{array}$} & \multicolumn{4}{|c|}{ Anti HBs (IU/ml) } \\
\hline & Mean \pm SD & Median & GM & $<10 />10(\% ; 95 \% \mathrm{CI})$ \\
\hline$(-)$ and $<400$ eosinophils $/ \mathrm{mm}^{3}$ & $191.1 \pm 401.2$ & 40.9 & 26.7 & $15 / 36(29.4 ; 16.8-41.9)$ \\
\hline$(+)$ and $>600$ eosinophils $/ \mathrm{mm}^{3}$ & $174.6 \pm 400.4$ & 20.2 & 18.6 & $18 / 28(39.1 ; 24.9-53.2)^{\mathrm{a}}$ \\
\hline
\end{tabular}

\section{DISCUSSION}

The utilization of a group with intestinal nematodes and/or Toxocara infection as a sample of children with helminth infection can be justified because the general mechanisms of the immune response to nematodes are similar, as demonstrated in experimental and human studies ${ }^{1415}$.

None of the children in either group presented significant symptoms or signs of any disease or undernutrition. The only manifestation was the presence of eosinophilia (eosinophil counts over $600 / \mathrm{mm}^{3}$ ), which was more frequent in the group with helminth infection (76.4 and $48.2 \%$ in the groups with and without helminthes, respectively; $\mathrm{p}=0.000$ ).
The results demonstrate that $33.8 \%$ of these healthy sevenyear-old children who were vaccinated at birth with recombinant HBV vaccine had anti-HBs titers lower than 10IU/l, without significant gender differences. This is the first report from Brazil on HBs titration seven years after vaccination of newborns, and the results are similar to those observed in other developing countries, in similar samples. The frequencies of anti-HBs titers lower than 10IU/1, five to 12 years after newborn vaccination with recombinant $\mathrm{HBV}$ vaccine have been reported to be lower in children from Canada ${ }^{6}$, Spain ${ }^{1}$, Italy ${ }^{9}$ and the United States ${ }^{25}$ than in children from Samoa ${ }^{26}$, Alaska ${ }^{20}$, Iran ${ }^{22}$ and Hawaii ${ }^{23}$.

Although still a matter for discussion, booster doses of vaccine for children with low anti-HBs titers do not seem necessary for ensuring long-term protection, even in endemic countries, despite 
waning or undetectable anti-HBs levels ${ }^{29}$. Studies on anti-HBs titers ten years after vaccination have demonstrated that strong immunological memory persists in infants and adolescents with a primary course of vaccination. Consensus groups in Canada, Europe and the United States have not recommended the need for booster doses under these circumstances, in immunocompetent individuals who responded to a primary course of vaccination ${ }^{8}$.

In the sample studied, none of the children had anti-HBc in the serum. It is difficult to interpret this finding because Vitória has a low prevalence of $\mathrm{HBV}$ infection, and it is therefore difficult to confirm whether this result indicates protection or absence of contact with the HBV virus.

The results demonstrate that the presence of helminth infection (intestinal worm, Toxocara infection or both) is unrelated to the anti-HBs titer decay in the sample studied. Even in children with helminth infection and blood eosinophil counts higher than $600 / \mathrm{mm}^{3}$, the anti-HBs titers were not significantly different from those observed in children without helminth infection and with blood eosinophils lower than $400 / \mathrm{mm}^{3}$. Although the results from stool examination were based on a single sample, the caveats originating from the assumption that false negatives might exist would be minimized by the low probability of helminth infection in children with blood eosinophils lower than $400 / \mathrm{mm}^{3}$.

Although there was no relationship between the presence of worm infection and the anti-HBs titers, we cannot rule out the possibility that worm infection might have an effect on memory cell response after a secondary antigen challenge. In fact, Ghaffar et $\mathrm{al}^{11}$ observed that the titers of anti-HBs were lower in children with schistosomiasis who received the vaccine after they acquired Schistosoma. The presence of Schistosoma infection reduced the response after primary vaccination.

In conclusion, the possible immunoregulatory effect of helminth infection does not seem to interfere with the maintenance of anti-HBs levels in children vaccinated at birth with the HBV recombinant vaccine. Further investigation is necessary to study the impact of helminth infection on the response of vaccinated children after a secondary challenge with HBV antigen.

\section{ACKNOWLEDGMENTS}

We thank Fabíola K C Ribeiro for language review.

\section{REFERENCES}

1. Ayerbe MC, Perez-Rivilla A. ICOVAHB group. Assessment of long-term efficacy of hepatitis B vaccine. European Journal of Epidemiology 17:50-56, 2001.

2. Bassily S, Kotkat A, Hyams KC, Youssef FG, El-Masry NA, Arthur R, Imam IZ, Brown FM. Immunogenicity of recombinant hepatitis B vaccine among infants of mothers with active schistosomiasis. The American Journal of Tropical Medicine and Hygiene 57: 197-199, 1997.

3. Brady MT, O'Neill SM, Dalton JP, Mills KH. Fasciola hepatica suppresses a protective Th1 response against Bordetella pertussis. Infection and Immunity 67: 5372-5378, 1999 .

4. Cooper PJ, Chico M, Sandoval C, Espinel I, Guevara A, Levine MM, Griffin GE, Nutman TB. Human infection with Ascaris lumbricoides is associated with suppression of the interleukin-2 response to recombinant cholera toxin B subunit following vaccination with the live oral cholera vaccine CVD 103-HgR. Infection and Immunity 69:1574-1580, 2001.

5. Diniz LM, Zandonade E, Dietze R, Pereira FE, Ribeiro-Rodrigues R. Short report: do intestinal nematodes increase the risk for multibacillary leprosy? The American Journal of Tropical Medicine and Hygiene 65: 852-854, 2001.

6. Duval B, Gilca V, Boulianne N, De Wals P, Massé R, Trudeau G, De Serres G Comparative long term immunogenicity of two recombinant hepatitis $B$ vaccines and the effect of a booster dose given after five years in a low endemicity country. Pediatric Infectious Diseases Journal 34: 213-218, 2005.

7. Elias D, Wolday D, Akuffo H, Petros B, Bronner U, Britton S. Effect of deworming on human $\mathrm{T}$ cell responses to mycobacterial antigens in helminth-exposed individuals before and after bacille Calmette-Guerin (BCG) vaccination. Clinical and Experimental Immunology 123:219-225, 2001.

8. European Consensus Group. Are booster immunisations needed for lifelong hepatitis B immunity? European Consensus Group on Hepatitis B Immunity. Lancet 355:561-565, 2000

9. Faustini A, Franco E, Sangalli M, Spadea T, Calabrese RM, Cauletti M, Perucci CA. Persistence of anti-HBs 5 years after the introduction of routine infant and adolescent vaccination in Italy. Vaccine 19: 2812-2818, 2001.

10. Ferreira AP, Aguiar AS, Fava MW, Correa J0, Teixeira FM, Teixeira HC. Can the efficacy of bacille Calmette-Guerin tuberculosis vaccine be affected by intestinal parasitic infections? Journal of Infectious Diseases 186: 441-442, 2002.

11. Ghaffar YA, Kamel M, Abdel Wahab MF, Dorgham LS, Saleh MS, el Deeb AS. Hepatitis B vaccination in children infected with Schistosoma mansoni: correlation with ultrasonographic data. The American Journal of Tropical Medicine and Hygiene 43: 516-519, 1990

12. Gourley TS, Wherry EJ, Masopust D, Ahmed R. Generation and maintenance of immunological memory. Seminars in Immunology 16:323-333, 2004.

13. Hayes KS, Bancroft AJ, Grencis RK. Immune-mediated regulation of chronic intestinal nematode infection. Immunological Reviews 201:75-88, 2004.

14. Maizels RM, Balic A, Gomez-Escobar N, Nair M, Taylor MD, Allen JE. Helminth parasites - masters of regulation. Immunology 201: 89-116, 2004.

15. Maizels RM, Yazdanbakhsh M. Immune regulation by helminth parasites: cellular and molecular mechanisms. Nature Reviews in Immunology 3:733-744, 2003.

16. Malhotra I, Mungai P, Wamachi A, Kioko J, Ouma JH, Kazura JW, King CL. Helminthand Bacillus Calmette-Guerin-induced immunity in children sensitized in utero to filariasis and schistosomiasis. Journal of Immunology 162: 6843-6848, 1999.

17. Moreira-Silva SF, Leite AL, Brito EF, Pereira FE. Nematode infections are risk factors for staphylococcal infection in children. Memórias do Instituto Oswaldo Cruz 97: 395-399, 2002.

18. Moreira-Silva SF, Pereira FE. Intestinal nematodes, Toxocara infection, and pyogenic liver abscess in children: a possible association. Journal of Tropical Pediatrics 46: 167-172, 2000.

19. Nookala S, Srinivasan S, Kaliraj P, Narayanan RB, Nutman TB. Impairment of tetanus-specific cellular and humoral responses following tetanus vaccination in human lymphatic filariasis. Infection and Immunity 72:2598-2604, 2004

20. Petersen KM, Bulkow LR, McMahon BJ, Zanis C, Getty M, Peters H, Parkinson AJ. Duration of hepatitis B immunity in low risk children receiving hepatitis B vaccinations from birth. Pediatric Infectious Diseases Journal 23: 650 655, 2004.

21. Sabin EA, Araujo MI, Carvalho EM, Pearce EJ. Impairment of tetanus toxoidspecific Th1-like immune responses in humans infected with Schistosoma mansoni. Journal of Infectious Diseases 173: 269-272, 1996.

22. Saffar MJ, Rezai MS. Long-term Antibody Response and Immunologic Memory in Children Immunized with Hepatitis B Vaccine at Birth. Indian Pediatics 41: 1232-1237, 2004.

23. Seto D, West DJ, Ioli VA. Persistence of antibody and immunologic memory in children immunized with hepatitis B vaccine at birth. Pediatric Infectious Diseases Journal 21: 793-795, 2002

24. Tristão-Sá R, Ribeiro-Rodrigues R, Johnson LT, Pereira FE, Dietze R. Intestinal nematodes and pulmonary tuberculosis. Revista da Sociedade Brasileira de Medicina Tropical 35: 533-535, 2002. 
25. Watson B, West DJ, Chilkatowsky A, Piercy S, Ioli VA. Persistence of immunologic memory for 13 years in recipients of a recombinant hepatitis $B$ vaccine. Vaccine 19: 3164-3168, 2001.

26. Williams IT, Goldstein ST, Tufa J, Tauillii S, Margolis HS, Mahoney FJ. Long-term antibody response to hepatitis $B$ vaccination beginning at birth and to subsequent booster vaccination. Pediatric Infectious Diseases Journal 22: 157-163, 2003.

27. Zuckerman JN. No response to hepatitis B vaccines and the kinetics of anti-HBs production. Journal of Medical Virology 50:283-288, 1996.
28. Zuckerman JN. Protective efficacy, immunotherapeutic potential, and safety of hepatitis B vaccines. Journal of Medical Virology 78:169-177, 2006.

29. Zuckerman JN, Connor BA, von Sonnenburg F. Hepatitis A and B booster recommendations: implications for travelers. Clinical Infectious Diseases 4:1020$1026,2005$. 